\title{
29- Memduh Şevket Esendal’ın “Bu Yollar Uzar” Adlı kısa öyküsünün metindilbilimsel açıdan incelenmesi
}

\section{Haydar ÖZDEMİR'}

APA: Özdemir, H. (2021). Memduh Şevket Esendal'ın "Bu Yollar Uzar” adlı kısa öyküsünün metindilbilimsel açıdan incelenmesi. RumeliDE Dil ve Edebiyat Araştırmaları Dergisi, (25), 452467. DOI: $10.29000 /$ rumelide.1036569.

\section{$\ddot{O} \mathbf{z}$}

Türk Edebiyatı’nın tanınmış öykü yazarlarından biri olan “Memduh Şevket Esendal”, günlük yaşamın her hangi bir kesitini ele alıp anlatan "Çehov Tarzı" öykü türü yazıların bilinen etkili isimlerindendir. Çehov'un karamsar yanı yerine yaşama ümit, neşe ve kuvvet veren yazılar yazmıştır. Eserlerinde sade, anlaşılır, temiz ve pürüzsüz bir üslup yaratarak her kesimden okuyucuya hitap etmiştir. Seçtiği konularda karmaşıklıktan uzak durmuş çoğu zaman sıradan insanların hayatlarına odaklanıp onların yaşamları hakkında yazılar yazmıştır. Bu çalışmanın amacı "Memduh Şevket Esendal”ın "Bu Yollar Uzar” adlı öyküsü, metindilbilimsel bağlamda çözümlenmektir. Yaygın metin incelemelerinden farklı olarak, metnin yüzeyinde yer alan unsurlardan hareketle derininde ortaya çıan anlamsal yapılara ulaşma yöntemi olan metindilbilim, çağdaş dilbilim araştırmalarında tümce boyutu aşılarak gerçekleştirilen çalışmalar neticesinde ortaya çıkmıştır. 1970'lerden beri dilbilimin farklı bir dalı olarak uğraş veren metindilbilim, metnin içindeki tümceleri birbirinden bağımsız unsurlar olarak değil, aralarındaki yapısal ve anlamsal bağlantılar yoluyla bir bütün olarak ele almaya başlamıştır. Çalışmada metin ve metindilbilim hakkında bilgiler verildikten sonra adı geçen öykünün; küçük ölçekli yapı, (sözcüksel bağlaşıklık, eşdizimsel örüntüleme, yineleme, dil bilgisel bağlaşıklık, gönderim, eksilti, bağıntı ögeleri, zaman uyumu ve görünüş, işlevsel tümce yapısı ve örtük anlatım) büyük ölçekli yapı/bağdaşıklık (işlev, konu, başlık, içerik şeması, anahtar sözcükler, konu tümcesi/ana düşünce tümcesi, sözdizimsel biçem özellikleri, dilsel, anlamsal biçem özellikleri, anlatıcı bakış açısı, özet ve sonuç tümcesi) tespit edilerek öyküde var olan metindilbilimsel görünümler ortaya çıarılmıştır. Çözümlemedeki temel amaç, metnin ana konusu ve bu konuyu meydana getiren alt konuların tespiti ve metnin görünen, anlaşılan kısmının yanı sıra derin yapısının yani metinde saklı olan unsurların meydana çıkarılmasıdır.

Anahtar kelimeler: Memduh Şevket Esendal, metindilbilim, çözümleme, kısa öykü

\section{Investigation of Memduh Şevket Esendal's short Story Through These Ways in terms of linguistics}

\begin{abstract}
Memduh Şevket Esendal, one of the well-known story writers of Turkish Literature, is one of the wellknown influential figures of "Chekhov Style" storytelling who deals with any part of daily life. Instead of Chekhov's pessimistic side, he wrote articles that gave hope, joy and strength to life. In his writings, he appealed to readers from all walks of life using a simple, smooth, clear and clean style. He avoided complexity and focused on the lives of ordinary people and wrote about their lives. The purpose in this research, Memduh Şevket Esendal's story "Bu Yollar Uzar ar is tried to be analyzed in the text
\end{abstract}

Arş. Gör., Hakkâri Üniversitesi, Eğitim Fakültesi, Türkçe ve Sosyal Bilimler Eğitimi Bölümü, Türkçe Eğitimi ABD (Hakkâri, Türkiye), haydarozdemir87@gmail.com, ORCID ID: oooo-ooo1-8621-7988 [Araştırma makalesi, Makale kayıt tarihi: 28.10.2021-kabul tarihi: 20.12.2021; DOI: 10.29000/rumelide.1036569]

Adres $\mid$ Address

RumeliDE Dil ve Edebiyat Araştırmalar Dergisi $\quad$ RumeliDE Journal of Language and Literature Studies

Osmanağa Mahallesi, Mürver Çiçeği Sokak, No:14/8 Osmanağa Mahallesi, Mürver Çiçeği Sokak, No:14/8

Kadıköy - ÍSTANBUL / TÜRKIYE 34714 Kadıköy - ISTANBUL / TURKEY 34714

e-posta: editor@rumelide.com e-mail: editor@rumelide.com,

tel: +90 505 7958124, +90 2167730616 phone: +90 505 7958124, +90 2167730616 
linguistic context. Unlike classical text analysis, text linguistics, which is a method of accessing the semantic structures emerging from the elements on the surface of the text, emerged as a result of the studies carried out by exceeding the sentence dimension in contemporary linguistics researches. Working as a separate branch of linguistics since the 1970s, text linguistics has begun to treat sentences within the text as a whole, not as independent elements, but as structural and semantic connections between them. After giving information about the text and linguistics in the study; small scale structure (lexical cohesion, iteration, syntactic patterning, grammatical cohesion, submission, subtraction, correlation elements, time matching and appearance, functional sentence structure and implicit expression) large scale structure/cohesion (function, title, subject, keywords, content schema, subject sentence/main thought sentence, syntactic style features linguistic, semantic style features, narrative perspective, summary and conclusion sentence). The purpose of the analysis is to identify the main subject of the text and the sub-topics that make up this subject and to reveal the visible, understood part of the text as well as the deep structure of the text, namely the elements hidden in the text.

Keywords: Memduh Şevket Esendal, text linguistics, analysis, short story

\section{Giriş}

Metin, doğru kelimelerin bir araya gelerek cümleler içerisinde uygun yerde bulunması ve ortaya çıkan cümlelerin de kendi aralarında anlamsal ve mantıksal yönden bir bütünlük oluşturması ile meydana gelen dilsel bir birliktir. Duvar nasıl tuğlaların özenle dizilmesiyle bir yapı olarak meydana çıkıorsa, metin de kelimelerin cümleler içerisinde doğru anlatımların seçilmesiyle ve bunların dikkatli bir şekilde oluşan yapı içerisine serpiştirilmesiyle meydana gelir. Bu doğrultuda ilk metin tanımlarından birini yapan Koch, metni: "Bir bütünsellik anlatacak biçimde zamanda ve uzamda düzenlenmiş her tür cümle dizilimidir." şeklinde tanımlamıştır (Aksan ve Aksan, 1991, s. 93). Halliday ve Hasan ise metin tanımı için şunu söylemektedirler: Metni tümceler bütünü olarak görmek yanlış olur. Onlara göre metin, dilin kullanımındaki birimdir ve tümce veya tümcecik gibi dilsel bir birim değildir ve büyüklüğüyle tanımlanamaz. Metin, biçimsel değil, anlamsal bir birliktir. Metin tümcelerden oluşmaz, tümceler tarafından gerçekleştirilir ya da tümceler içinde kodlanır. Buna göre metin sözlü veya yazılı, mensur veya manzum, diyalog veya monolog biçiminde olabilir. Tek bir atasözünden tüm bir oyuna, bir anlık yardım çağrısından bir topluluktaki tüm gün süren bir tartışmaya kadar her şey metin olabilir. Metnin özünde biçimsel birlik değil, anlamsal birlik vardır. Metin kendisini oluşturan tümcelerin toplamından farklıdır (Halliday-Hasan,1976: 1-2). Bu kurallar çerçevesinde oluşturulmuş bir metni araştırma konusu yapan "metindilbilim" geleneksel dil bilgisinden ve metin çözümleme biçimlerinden farklllaşan bir yaklaşımdır. Vitacolonna Hartmann’ın 1964’te yazdığı text, texte, Klassen von Texten başlıklı makalesini metindilbilimin başlangıcı olarak kabul edilir. Hartman, insanlar birbirleriyle kelime veya tümceler vasıtasıyla değil metinler aracılığıyla iletişim kurduğu söyleyerek bundan dolayı da çalışmaların odak noktasının metin olmasını ileri sürerek metindilbilim adına bir dönüm noktası oluşturmuştur (Şenöz, 2005: 17-18). Metindilbilim ile alakalı yerel çalışmalara bakıldığında Berke Vardar'ın metinbilim yerine betimsel dil bilim tanımını kullandığı görülür. "Söylem Çözümlemesi” için de cümle sınırlarını aşarak daha üst düzeyde var olan söz varlıklarına yönelen çözümleme olduğunu söylemektedir. Hengirmen metindilbilimini, dili cümleler arası bağlantıları temel alarak inceleyen dil kullanımını metin üretme olarak gören metinleri bir bütünlük içinde ele alan bilim dalı olarak tanımlamış (Vardar, 2002, s. 39). Sözlem çözümlemesinde ise yine Vardar gibi cümlenin sınırlarının aşılması olarak benzer bir tanımlama yapmıştır (Hengirmen, 1999, s. 276). Bu söylenenlere bakıldığında cümleden daha fazla sözcenin söylem çözümlemesini meydana getirdiği görülür.

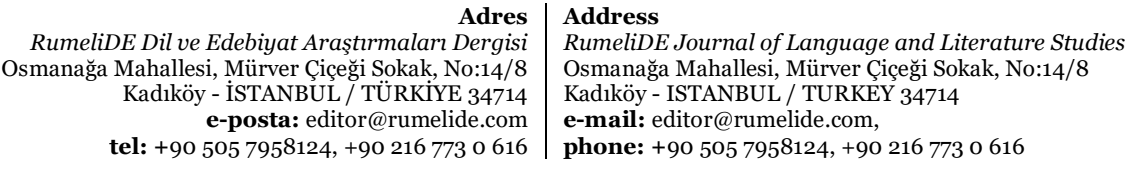


Dilbilimle alakalı yapılan çalışmalarda yazınsal söylemen fazla incelenen söylem türü olmasından dolayı metinbilimi kavramını ortaya koymuştur. Böylece metnin farklı yapıları bu yeni alanla ortaya konulmuştur. Her çeşit metin çözümlemenin özünü metin kavramı, dil edimleri ve metinsel tutarlılık kavramları oluşturmuştur (Kıran, 2001, s. 279). Söylem çözümlemesiyle metindilbilim biri yazılı diğeri sözlü ürünleri incelemeleri bakımından ayrılsalar da söylem çözümlemesi metindilbilim için bir bakış açısı oluşturmaktadır. Metindilbilime göre yapılan incelemelerde, metnin içindeki tümceler ayrı değil, metni bütün olarak oluşturan dil bileşenleri arasındaki bağıntılar ile metnin bir bütün olarak işlevi ve yapısı önemlidir. Bu doğrultuda metne yaklaşan metindilbilim, metin türüne bakılmaksızın her türlü dil olgusunu metin yapan kural ve ölçütleri belirler. Farklı metin türleri arasındaki değişik yapısal ve işlevsel özellikleri belirler. Metinler vasıtasıyla gönderme yaptıkları nesnel olgular arasındaki ilişkileri araştırır, metinlerin birçok katmanlı anlamsal yapılarını tespit eder. Dijk’e göre, metnin anlambilimsel yapısı (coherence) hem bir dizi tümce düzeyinde (küçük) hem de metnin bütünü düzeyinde (büyük) betimlenebilir. Metnin küçük yapısını, metnin bir yerindeki tek tek önermelerin yapısı ve bunlar arasındaki ilişkiler oluşturmaktadır. Büyük yapı ise bir bütün olarak metnin oluşturulması ile ilgilidir. Dijk'e göre, büyük yapı, tümcelerin derin yapısı ile örtüşmeyen, onların temelinde var olan bir anlambilimsel metin derin yapısına işaret eder (Akt. Aydın \& Torosda $\breve{g}, 2014$ ). Metinler, üstlendikleri işlevleri kullanıldıkları bağlam sayesinde ortaya çıkarır. Metindilbilimin sunduğu bu bakış açısı, Dilidüzgün (2008), Aydın ve Torusdağ’ın (2013) da söylediği gibi metinlerin daha çok anlaşılmasına ve yorumlanmasına yardımcı olurken, ortaya çıarılan metinlerin de daha fazla işlevsel olmasına katkı sağlayacaktır.

İlk defa okunduğunda anlaşllamayan, çözümlenemeyen, dikkatli ve özenli bir okuma yöntemi ile zaman gerektiren yazınsal metinler metin dilbilimsel çözümlemeler ile daha net anlaşılmakta, metin yazarının söylemek istediklerine ve mesajına zahmetsiz bir şekilde ulaşlmaktadır. Metnin temel konusu ve temel konuyu destekleyen alt konularının belirlenmesi, metnin görünen yapısının ötesinde derin-örtük yapısının ortaya çıkarılması metinbilim sayesinde olmaktadır. Bu doğrultuda inceleme konusuna yaklaşan metinbilim yapı taşı dil olan öykü, roman, deneme gibi farklı türleri metin yapan ölçüt ve kuralları saptar. Bu bağlamda kısa öyküler de metin özellikleri taşıdıklarından metindilbilimin araştırma alanına girmektedirler. Bu çalışmayla daha önce metin çözümlemesi yapılmayan Memduh Şevket Esendal'ın "Bu Yollar Uzar" isimli kısa öyküsünün metindilbilimsel bir bakış açısıyla çözümlenmeye çalışılmıştır. Çözümlemedeki amaç metnin temel konusu ile bu temel konuyu oluşturan alt konuların tespitinin yapılması ve metnin yüzeyde görünen, anlaşılan kısmının ötesinde anlaşılması zor olan derin yapısının yani metinde saklı-örtük olan unsurların ortaya çıkarılmasıdır.

\section{Yöntem}

$\mathrm{Bu}$ araştırmada Memduh Şevket Esendal'ın “Bu Yollar Uzar” adlı kısa öyküsü ele alınarak metindilbilimin araştırma alanına giren iki ögenin varlığına değinilmektedir: küçük ölçekli yapı, (sözcüksel bağlaşıklık, yineleme, eşdizimsel örüntüleme, dilbilgisel bağlaşıklık, gönderim, eksilti, zaman uyumu, bağıntı ögeleri, görünüş, işlevsel tümce yapısı ve örtük anlatım) ve büyük ölçekli yapı/bağdaşıklık (işlev, konu, başlık, içerik şeması, anahtar sözcükler, konu tümcesi/ana düşünce tümcesi, sözdizimsel biçem özellikleri dilsel, anlamsal biçem özellikleri, özet, anlatıcı bakış açısı ve sonuç tümcesi). Küçük ölçekli yapıyla ilgili bağlaşıklık ölçütleri Halliday-Hasan (1976) ve Beaugrande Dressler'den (1981) esinlenerek ele alınırken, büyük ölçekli yapı ile ilgili bağdaşıklık ölçütleri Beaugrande-Dressler (1981) ve Aydın ile Torusdağ’’n oluşturduğu modelden (Aydın ve Torusdağ, 2014: 117) esinlenerek ele alınmaya çalışılmıştır. Öyküde bu yapıların nasıl ortaya çıktığı açılanmaya çalışılmıştır.

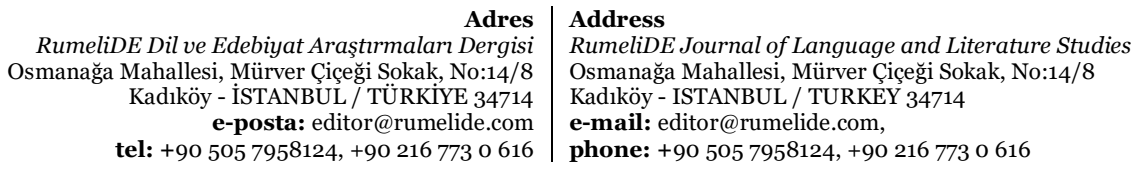


Bu çalışmanın verileri, Yıldırım ve Şimşek'in (2003) belirtmiş olduğu nitel araştırmalar için kullanılan veri toplama yöntemlerinden biri olan "yazılı dokümanların incelenmesi" yöntemiyle toplanmıştır. Çalışma için toplanan veriler betimsel analiz yöntemiyle analiz edilerek yorumlanmaya çalışılmıştır. Bu şekilde bir analiz yapılarak metnin derin/örtük yapısında yer alan anlam katmanları ortaya çıkarılmıştır.

\section{Bulgular}

Çalışmanın bulguları aşağıda başlıklar şeklinde verilmiştir.

\section{Küçük ölçekli yapı/bağlaşıklık}

Bağlaşıklık, metinde oluşan anlama bakmadan metnin yüzey yapısında meydana gelen dilsel öğeler arasındaki ilişkidir. Metnin küçük ölçekli yapı bağlamında ele alınması, metnin yüzeysel betimlenmesini ve metnin dilsel yapıda ele alınmasını ve onun metin düzeyinde değil de tümceler düzeyinde değerlendirilmesini gerektirir. Bir metinde bütünlüğün sağlanması için birtakım bağlantıların kullanılması gerekir. Bunu oluşturmada tek ölçütün bağlaşıklık olduğunu ifade eden (Haliday ve Hasan, 1976:9)'a göre, bağlaşıklık kavramı, bir metnin ne anlama geldiğinden çok o metnin anlamsal bir yapı olarak nasil oluşturulduğudur.

\subsection{Sözcüksel bağlaşıklık}

Bir metnin küçük ölçekli yapısında sözlüksel birimlerin kullanımı ile ilgili olan sözcüksel bağlaşıklık büyük ölçekli yapıyı hazırlayan dilsel düzenlemeleri içerir. Aynı doğrultuda anlamsal bir sürekliliği olan metinlerin bağlaşıklı̆̆ üzerinde çalışmak bir yönüyle sözcükler üzerinde çalışmayı gerektirmektedir. Ancak bu sözcükler bulundukları bağlamdan bağımsız olarak ele alınamazlar. Zira sözcükler bir bağlam içerisinde kullanıldıklarında temel anlamlarının dışında farklı bağlamsal anlamlar kazanırlar. Bir metnin bağlaşıklık yapısını incelerken o metnin söz varlığı ile ilgili düzenlemeler ön plana çıkmaktadır. Sözcüksel bağlaşıklı, bir dilde açı liste oluşturan sözlük birimlerden yapılan seçimler sonucunda gerçekleştirilen bir bağlaşıklık biçimidir. En genel ifadeyle, sözcüksel bağlaşıklık sözcüklerin yinelenmesidir (Dilidüzgün, 2008: 74). Ancak aynı bağlamda kullanıldıkları için birbirleriyle ilintili hale gelmiş ya da doğrudan birbirleriyle ilintili sözcüklerin eşdizimlenmesi de sözcüksel bağlaşıklı̆̆ın bir başka biçimidir.

\subsection{Yineleme}

Yineleme, bir metinde art arda ya da metnin farklı yerlerinde tekrar edilmiş sözcükler olduğu bilinmektedir. Yineleme, metindeki bağlaşıklı̆ga katkıda bulunan önemli bir unsurdur. Dil bilgisel düzlemde tümceler arasındaki bağları kurup metnin anlaşılmasını önemli ölçüde sağlarlar. (Haliday ve Hasan, 1976:288). Her dilde bir durumu, bir nesneyi, bir varlığı ifade etmeye yarayan farklı dil öğeleri vardır. Metinde yer alan bir öğenin, bir adılla ya da farklı adlarla, farklı biçimlerle ifade edilmesi, o öğenin metin boyunca yinelenmesini dolayısıyla tümceler arasında bağlantının kurulmasını sağlar.

Öyküden alınan ardışı cümlelerdeki 'çırak' sözcüğü, aynı sözcüğün yinelemesine örnek oluşturmaktadır:

Belediye kâtibine bir kâğıt götürmüştü, önerken kasabın çırağına rast geldi. Çırak onu görünce durdu.

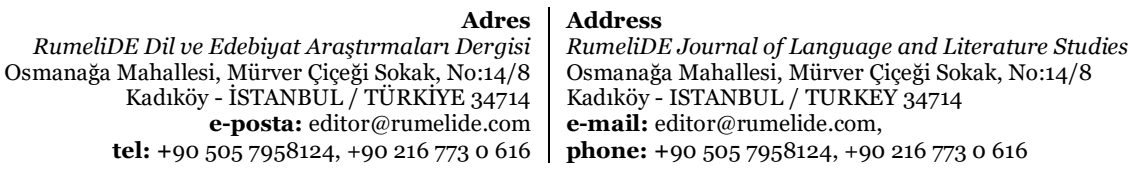


Eller kelimesinin yineleme örneği için: "Elleri titriyor. Elbet bir şey var ki ellerim böyle titriyor." şeklinde verilmiştir.

Hayri kelimesinin yineleme örneği için: “Hayri’yi kuyu başına çekiyordu. Hayri sevindi.” Şeklinde verilmiştir.

Halil Usta kelime gurubunun yineleme örneği: Yetim Mehmet’in evinin köşesinde Semerci Halil Ustaya karşı geldi.

Bahçe büyük ağaçlar da kapıyor, kimler olduğu görülmüyor. Eğildi, ağaçların altına baktı.

Git bakalım... Git yaaa!

Bir gün gelir bu yollar sana da uzar anladın mı? Bu yollar sana da domuzlaşır.

Yukarda belirtilen tümcelerde geçen yineleme kelimeleri öncelikle metindeki bağlaşıklığı sağlamış ve tümceler arasındaki anlaşırlığı pekiştirmiştir.

\subsubsection{Eş anlamlı, zıt anlamlı ya da yakın anlamlı sözcüklerin kullanımı}

Nitelikli metinler oluşturmak için metin türüne uygun olarak eş anlamlı, zıt anlamlı ve yakın anlamlı kelimelerinin kullanılmasının yanı sıra sözcüklerin aynı sözcüklerle yenilenmesi de gereklidir. Öyküde belirtilen 14. tümcede 'sıkıntı' sözcüğü 'ateş' yakın anlamlısıyla, 36. tümcede 'gözlerini bürümek' eylemi 'tanımak' yakın anlamlısıyla, 52. ve 53. tümcelerde 'oynuyorlar' sözcüğ̈̈ 'bağrışıp gülüşüyorlar' yakın anlamlısıyla, 65. Tümcede 'karışma' sözcüğü 'git işine' yakın anlamlısıyla yinelenerek anlam zenginleştirilmiş ve konu sürekliliği sağlanmıştır.

\subsection{2. Üst terim-alt terim ilişkili sözcük kullanımı}

Kelimelerin üst terim-alt terim ilişkisi içinde yenilenmeleri, metnin bağlaşıklık özelliğini sağlar. Bu tip kullanım biçimleriyle sözcük bakımından zenginleştirilen metinlerde konu bütünlüğü ve metin bağlaşıklığı sağlanmış olur.

Örnek olarak: 3. tümcede 'çırak' terimi alt terim, 4. tümcede 'usta' üst terimiyle, 12. tümcede 'evli’ üst terimi 13. tümcede 'karısı' alt terimiyle yinelenmiştir:

Çırak onu görünce durdu. (3) Hayri’ye: Kuzu ciğeri istemişsin, dedi, usta ayırdı. (4)

Ulan şu ettiğiniz işe bakın be! İçinizde bu evli, bu da evli kendi kız kardeşini göstererek bu da sözüm yabana nişanlı.(63) Tümcesinde 'nişanlı' alt terim 'evli' kelimesi de üst terim olarak kullanılmış.

\subsubsection{Genel kavramlar kullanma}

Halliday ve Hasan (1976)'a göre, kapalı bir sistemin elemanı olan dilbilgisel kavramlar ile açık bir sistemin elemanı olan kelimeler arasındaki sınırda genel kavramlar bağlaşıklık işlevi görürler. Bu genel kavramlar kişi, insan, kadın, erkek, çocuk, kız (insan), yaratık (insan dışı canlı varlık), şey, nesne (cansız somut sayısı), şeyler (cansız somut kümesi), iş alanı, olay, konu (cansız soyut), hareket (eylem), yer ve sual, fikir (durum) vb. küçük bir sözcük dizisi ile sınıflandırılabilir. Bu kullanım biçimi şöyle örneklendirilebilir:

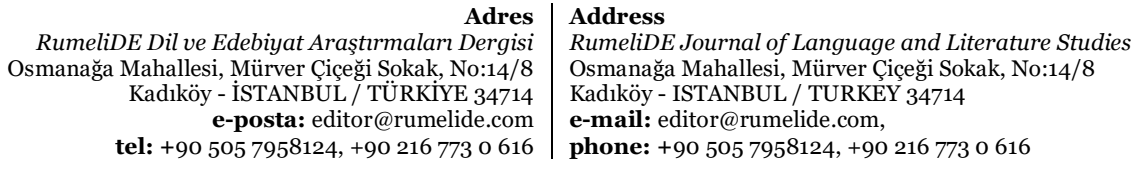


Postacı Hayri yirmi altı yaşında bir delikanlı. (1) Adamın aklına en olmayacak şeyler gelir. (17) Burada kullanılan genel kavramlara bakıldığında: kuzu, ciğer, usta ve çırak kelimelerinin genel kavram anlamında kullanıldığı görülür.

Posta kavramı için Postacı Hayri, postahane, posta günü ve kâğıt kelimeleri kullanılmış.

Akraba kavramı için kız kardeş, hısım kızları, karı ve evlilik kelimelerini kullanılmış.

\subsection{Eșdizimsel örüntüleme}

Metinde konu bütünlüğü sağlamanın bir diğer yolu da, eşdizimsel örüntüleme olarak bilinen, aynı kavram alanından aynı bağlamda kelimeler kullanarak bağlantılı tümceler oluşturmaktır (Uzun, 1995: 64; Dilidüzgün, 2008: 78). Doğan Aksan kavram alanını şöyle açıklamaktadır: "Kavram alanını biz, birbirine yakın ve birbiriyle ilişkili kavramların, anlamdaş kelimelerin içinde düşünüldükleri alan" olarak tanımlıyoruz. Türkçedeki bezmek, bıkmak, usanmak, bezginlik, usanç, bıkkınlık, bıkkınlık getirmek... ögelerinin bir kavram alanı içinde düşünülebilecekleri muhakkaktır. Fakat asıl önemli olan yön bizim için, kavramların değerlerinin bu alan içinde belli edilebilmesi değil, belleğin nasıl işlediği, dil denen sistem içindeki çeşitli ögelerin, okuma, yazma konuşma esnasında nasıl seçildikleridir.

Bu çalışmada eşdizimsel örüntülenen kelimelerden yola çıkarak metinlerdeki motifler tespit edimeye çalışılmıştır. Bu bağlamda, eşdizimsel örüntü örnekleri aşağıdaki gibidir:

Kasap motifi için: Kuzu, ciğer, usta ve çırak kelimeleri kullanılmış.

Posta motifi için: Postacı Hayri, postahane, posta günü ve kâğıt kelimeleri kullanılmış.

Akraba motifi için: Kız kardeş, hısım kızları, karı ve evlilik kelimelerini kullanmış.

Âşık motifi için: Gözünden kıskanmak, yüzüne bakıp gülmek, sevinmek, bağrına basmak, kucaklamak, kırk yldır görmemek ve doyamamak kelimelerin eşdizimlenmesiyle oluşturulmuştur.

\subsection{Dil bilgisel bağlaşıklık}

Dilbilgisel bağlaşıklık, kelimeler, kelime grupları, eylem zamanları ve cümleler arasında kurulan dilbilgisel ilişkilerle sağlanır. Başka bir deyişle metnin genel anlamı ya da metnin en büyük ölçekli önerisi dilbilgisel bağların yorumunda saklıdır.

Metnin genel anlamını meydana getiren dilbilgisel bağlaşıklık, Beaugrande-Dressler (1981) ve HallidayHasan (1976) 'a göre, (değiştirim, gönderim, eksilti, bağlaçlar, zaman ve görünüş, koşutluk, devrik cümle ve fonksiyonel cümle yapısı) gibi dil sistemleri ile elde edilir.

\subsection{Gönderim (Ön gönderim, art gönderim)}

Beaugrande ve Dressler (1981: 61)'in belirttiği gibi, çoğunlukla bir metinde yüzey yapıyı kısaltan ve sadeleştiren bağlaşıklık düzenekleri kullanılır. En belirgin bağlaşıklık düzeneği, ekonomik ve kısa sözcükler kullanımı olan gönderimlerdir. Bilinen en iyi gönderim öğeleri sözcük ya da sözcük grupları yerine kullanılan adıllardır Ön gönderimler, henüz metne dâhil olmamış, ancak daha sonra dâhil

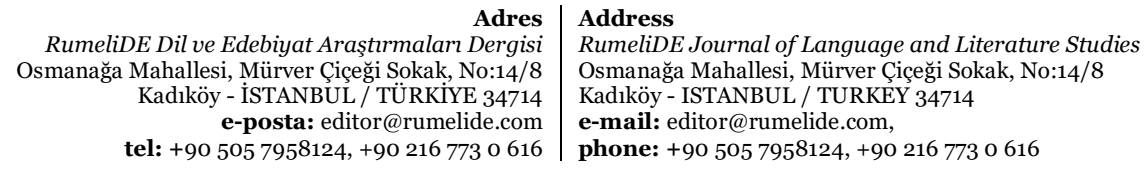


edilecek unsurlara yapılan gönderimlerdir. Metinde detaylarına sonra değinilecek, şahıs kavram ya da olaya metnin başlangıcında kısaca yer verilmesidir.

Art gönderim, bir kelime veya kelime grubunun daha önce kullanılan bir kelimeye gönderimde bulunmasıdır. Günay (2013: 77-79)'ın ifadesiyle, "Genel metin içinde bir şey önce söylenir, sonra aynı şeye gönderimde bulunulur."

Postacı Hayri, yirmi altı yaşında bir delikanlı. Belediye kâtibine bir kâğıt götürmüştü. (1)

2. tümcede 'götürmüş̧ü’ yüklemin öznesi olan O 3. tekil kişi öznesi ile 1. tümcedeki ‘Hayri’ sözcüğüne art gönderim yapılmıştır.

“Evde kimse yoktu” sözü kulağını tırmaladı.( 7) tümcedeki kulağını iyelik eki 1. tümcedeki Hayri’nin art gönderimidir.

Recep, dedi, sen buradan ayrlma. (19) Beni yukardan sorarlarsa, belediyeye gitti de. (20) Ben eve kadar bir gideyim.(21) 20. Tümcedeki gizli özne olan sen 19. tümcedeki Recep’in yerine art gönderim olarak kullanılmış. 21. Tümcedeki ben öznesi ise 1. ve 2. tümcedeki Hayri’nin yerine art gönderim olarak kullanılmış.

Kapının săg yanında her gün oturdukları odaya baktı. Yok. ( 31) Yattıkları odanın kapısını açarken içerde karısını bir yabancıyla görecekmiş gibi geliyordu. (38) 31. tümcedeki o öznesi 38. Tümcedeki karısının ön gönderimidir.

\subsection{Eksilti}

Eksilti, bir cümleden bir veya birden fazla öğenin silinmesi işlemidir. Kurulan bir cümlede bazı öğeler anlaşılmada zorluk yaratmadan ya da anlam kaybına yol açmadan eksik olabilir, kullanılmayabilir, atılabilir veya silinebilir (Vardar, 1988: 95). Konuşma dilinde, iletişim için gerek görülmeyen hiçbir şey kullanılmaz. Tümcenin anlaşılır olması ve kaybolmaması için eksiltili inşaların mantıksal ve dilbilgisel açıdan doğru kurulmuş olması şarttır.

Eksiltili ifadeler doğru yerde kullanılırsa özgün ve kapsamlı bir anlatım tarzı oluşturulabilir. Düşünceler, özlü ve kısa biçimde bu çeşit kullanımlarla ortaya çıkarılmış olur. Bu yüzden eksiltili yapılarda, eksik olarak dile getirilmiş anlamlı yapıyı özümsemek gerekir. Eksiltili yapıları Türkçede şu şekilde türlerine ayırabiliriz: Yüklem eksikliği, özne eksikliği, nesne eksikliği, tümleç eksikliği, tamlayan eksikliği ve tekrardan ortaya çıkan eksiltili yapılar.

Aşağıdaki tümcelerde, özne, tamlayan ve yüklem eksiltisi görülmektedir:

Postacı Hayri yirmi altı yaşında bir delikanlı.(1) Yüklem eksikliği.

“Evde kimse yoktu” sözü (onun) kulağını tırmaladı. (7)Tamlayan eksikliği.

(O) “Yürüdü, postahaneye gitti.” (12) (O)”Altı aylık evlidir.” (15) (O)”Postahanede duramadı.”(18) Özne eksikliği.

(Ben) "Şimdi gelirim.” (22) Özne eksikliği.

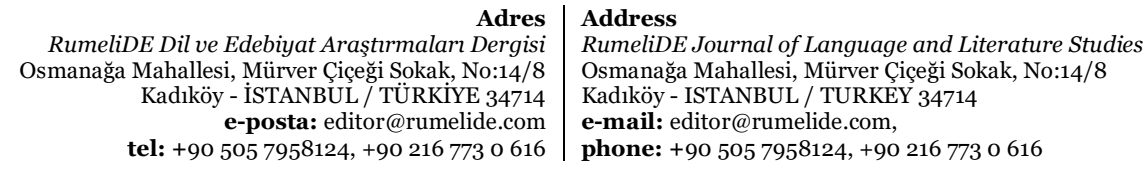


(O) “Nereye gitti?” Özne eksikliği.

“Komşular duydular.” Nesne eksikliği.

“Kasaptan ciğeri aldı, bir solukta ev...” Özne ve yüklem eksikliği vardır.

Hikâyede geçen tümcelerin çoğunda özne eksikliği bulunmaktadır. Yazar gereksiz sözcük kullanmadan eksiltili ögelerin okuyucu tarafından tamamlanmasını tercih etmiştir.

\subsection{Bağıntı öğeleri}

Metinler, birden çok tümce arasındaki sözdizimsel ve anlamsal bağlantılar, ilişkiler sonucunda ortaya çıkmış yapılardır. Bir metinde bağıntı, dilbilgisel olarak da, olaylar arasında mantıksal bağlar kurarak da sağlanır. Kendi başlarına anlamları olmayan, yer aldıkları cümlenin ve metnin çeşitli kısımları arasında anlamsal ve bütünsel ilişki kuran bağıntı öğeleri aracılığıyla cümleler arasında anlatım ve konu bütünlüğü sağlanır. Cümle içinde anlamca birbiri ile ilgisi bulunan ya da aynı görevde olan kelimeleri, kelime gruplarını, anlam açısından birbiri ile ilgili cümleleri bağlayan kelimeler en genel ifadeyle bağıntı öğesi olarak adlandırılır. Bunlar, tümcede birden çok özne, belirtili nesne, zarf, sıfat, tamlayan, tamlanan, yüklem vb. görevde bulunan her türlü sözcüğü ve cümleyi birbirine bağlayan kelimelerdir.

Beaugrande ve Dressler (1981: 74-75)'e göre, bir metinde, geleneksel dilbilgisinde gelişigüzel bir biçimde hepsine bağlaç denilen, bağlayıcı ifadelerin kullanımı, durumlar veya olaylar arasındaki bağlantıyı gösteren bariz bir düzenektir.

Öyküde geçen bağlaçlı tümceler aşağıda belirtilmiştir:

"Elbet bir şey var ki ellerim böyle titriyor. "(27) Burada kullanılan "ki” bağlacı iki cümleyi birbirine bağlamıştır.

"Kapının arkasında, çiviye asılmış bir erkek ceketi ile bir pantolon var." (32) Burada kullanılan "ile" bağlacı farklı giysileri cümle içerisinde bir arada kullanılmasını sağlamıştır.

"Kıskançlık gözlerini bürümüş, görüyor da tanımıyor." (36) Burada kullanılan “da” bağlacı iki yüklemin bir cümlede kullanılmasını sağlamış.

"Orası da boş." (38) Burada kullanılan da başka yerlerin boş olduğu gibi burasının "da” boş olduğu anlamını sağlamıştır. Bir nevi karşılaştırma yapılmasını sağlamış.

"Koştu, ciğeri elinden aldı, mutfağa girdi, oradan da sabunla el havlusu getirdi." (55) Burada kullanılan "da" bağlacı iki cümleyi birbirine bağlamış.

“Ulan, dedi seni alan herifin de kaz kadar beyni var mı?” (68) Burada kullanılan "da” bağlacı herifi diğer bireylerle karşılaştırma yapılmasını sağlamış.

\subsection{Zaman uyumu ve görünüş}

Bir metnin bağlaşıklığı, görünüş, dilbilgisel zaman ve kip gibi unsurlar ile belirtilmektedir (Günay, 2013: 93). Bunlar çeşitli dillerde çok farklı şekillerde düzenlenirler. Bir anlatı metni olan öyküde, aktarılan olaylar belli bir süre içinde geçer. Metindeki olay ve durumlarla ilgili göreli zamanlar, olayların

\footnotetext{
\begin{tabular}{r|l} 
Adres & Address \\
RumeliDE Dil ve Edebiyat Araştırmaları Dergisi & RumeliDE Journal of Language and Literature Studies
\end{tabular} Osmanağa Mahallesi, Mürver Çiçeği Sokak, No:14/8 $\quad$ Osmanağa Mahallesi, Mürver Çiçeği Sokak, No:14/8 Kadıköy - ÍSTANBUL / TÜRKIYE 34714 Kadıköy - ISTANBUL / TURKEY 34714 e-posta: editor@rumelide.com e-mail: editor@rumelide.com, tel: +90 505 7958124, +90 2167730616 phone: +90 505 7958124, +90 2167730616
} 
birlikteliğini ve belli bir sıraya göre dizilmesini sağlar. Öykü, kendi aralarında belli bir mantık ve zaman ilişkisi içinde eklemlenmiş gerçek ya da kurmaca olaylar dizisidir. Dolayısıyla metin üretici, anlattığı olayları gerçekliğe dayandırabilmek için zaman bağlantıları kullanır. Oluşturduğu metni belli bir döneme, zamana, mevsime, saate oturtmak zorundadır.

Hikâyede geçen olaylar kısa bir zaman diliminde meydana gelmiştir. Öyküde zaman kavramıyla ilgili geçen tümceler şu şekildedir:

Postacı Hayri 26 yaşında bir delikanlı. (1)

Altı aylık evlidir. (15) Öyküde zaman kavramıla ilgili olarak geçen bu iki tümce öykünün kurgusal zamanla ilgili olmadığı görülmektedir.

Çırağın ciğeri eve götürmesi, Hayri’nin posta dağıtımındayken eve gidip gelmesi, Hayri’nin eşi ile komşu kızların bahçede oynaması ve geceler yetmiyor mu tümcelerinden öykünün kurgusal zamanından haberdar oluyoruz. Bu tümcelere bakarak hikâyenin bir günün gündüzünde meydana geldiğini anliyoruz.

\subsection{0 Örtük anlatım}

Örtük anlatım daha çok yazınsal metinlerde kullanılan biçemsel bir özelliktir. Bu metinlerde açıkça ifade edilmemiş ancak diğer önermelerden yapılan çıkarımlar sonucunda anlaşlan önermeler örtük anlatım örnekleridir. Yazarlar söylemek istediklerini bazen doğrudan ifade etmekte bazen de biçemsel özellikleri olarak örtük bir biçimde ifade etmektedirler. Örneğin, "Hava sıcak." cümlesinde yazılanın ötesinde ne anlatılmak istenmektedir. Bu cümleden; pencereyi aç, ısı ayarının kapat, ceketimi çıkartabilir miyim? gibi anlamlar çıkartılabilir (Günay, 2018: 340).

Anlatıda dış dünya gerçeğinden yola çıkan yazar, dil düzeyinde elinden geldiğince dış dünyayı, gerçeğe yakın ve eksiksiz bir şekilde yeniden yapılandırmaya çalışır. Ancak bu gerçeklik dünyanın dış gerçekliğini ne kadar ele verse de dış dünyayı anlatısına ilave ederken tutumluluk ilkesiyle hareket eder. Dil dışı göndergelerin bütün ayrıntılarını, özelliklerini anlatısında olduğu gibi yansıtamaz. Dolayısıyla örtük anlatımlara, sezdirimlere başvurur. Metin çözücü de kendi kültürü ve düş gücünün verdiği olanaklar ile çıkarımlarda bulunur. Anlatılmak isteneni sezgi yoluyla anlatır.

Hikâyede geçen örtük anlatımlar şu şekildedir:

"Evde kimse yoktu” sözü kulağını tırmaladı. (7) Bu tümcede Hayri’nin duymak istemediği bir cevap karşısında kendisinde oluşan rahatsızlık dile getirilmiş̧ir.

Yüreğinde bir sıkıntı, bir ateş. (14) Altı aylık evlidir. (15) Karısını gözünden kıskanıyor.(16) Adamın aklına en olmayacak şeyler gelir!...(17) Bu tümcelerle yeni evliliğin verdiği heyecanla eşinin kıskanan birinin en ufak bir olumsuzluk durumunda aklına kötü şeylerin geldiği ima edilmektedir. Aşk adamın gözünü kör eder, cümlesi burada tam da anlamını buluyor. Aşk insanı sarhoş ettiğinde bu durumda yapılan davranışlarda mantık aramak doğru değildir.

Kapının arkasında çiviye asılmış bir erkek ceketi ile bir pantolon var. (32) Buz gibi oldu. (33) "Bunlar kimin” diye düşündü. (34) Kendisinin! Kıskançlık gözlerini bürümüş, görüyor da tanımıyor. (36) Bu

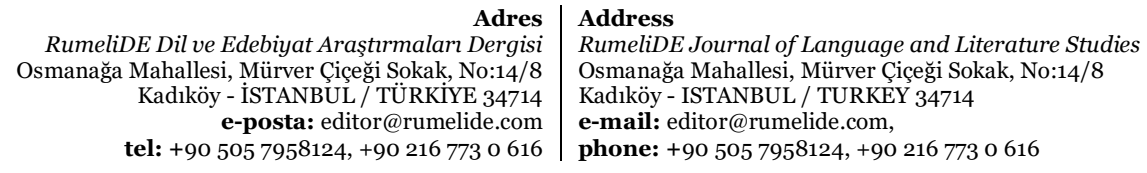


tümcelerde kıskançlı̆̆ın verdiği huzursuzluk bireyin gözlerinin kararabileceği ve kendi elbiselerini bile tanımayacak duruma gelebileceği anlatılmaktadır.

"Ulan şu ettiğiniz işe bakın be! (63) İçinizde bu evli, bu da evli - kendi kız kardeşini göstererek - bu da sözüm yabana, nişanlı. Kalanınız da at gibi kızlar, bağırtınızdan deniz kıyısında durulmuyor!”(64) Tümceleriyle orda olan herkesin yaptıkları işle yaşlarının uygun olmadığı ve çıkardıkları gürültünün çok uzaklarda duyulduğu anlatılmaktadır.

"Ulan, dedi seni alan herifte kaz kadar beyin var mı?” (68) Bu tümcede damadının böyle bir kadınla evlendiğinden aklının kıt olabileceğini ima etmektedir.

Canım ne yapıyorsun? ...(78) Çocuk musun? ...(79) Tümcelerinde yapılan davranışın doğru ve zamanı olmadığı anlaşılmaktadır.

"Ama bu işler e böyle sürer sanma! (95) Benim de günde üç yol eve gidip dükkâna döndüğüm olurdu. Sonra yollar uzadı. Şimdi tövbeler olsun... İkindiyin dükkândan çıkıyorum, akşama eve zor yetişiyorum. Bir gün gelir bu yollar, sana da uzar anladın mı? Bu yokuşlar sana da domuzlaşır. Tıknefeste at gibi solur solur da çlkamazsın. Bak bana! Gidi gençlik...”(104) 95 ve 105. tümceler arasında bir gün gençliğin verdiği heyecanın biteceği, gençliğin yerine yaşlılığın yer alacağı, gençken yokuşları geçmenin ne kadar kolay olduğu, evlilik heyecanın bir gün biteceği zamanın geçtiğini ve hayatın sürekliliğinden bahsedilmektedir.

\section{Büyük ölçekli yapı/bağdaşıklık}

Metinler küçük ölçekli analizlerle açlklanamaz. Bir metnin genel anlamına ulaşabilmek için küçük ölçekli yapı çözümlemelerin yanı sıra büyük ölçekli yapı üzerinde bir değerlendirme ve analiz yapılmalıdır. Büyük ölçekli yapılar metinde 'anlamsal nesneler'dir, algılanan ve üretilen metnin anlamını oluşturur.

Metin çözümlemelerinde yüzeyden derine inen bir çizgi (yapı) söz konusudur. Biçimsel olarak metnin yüzey yapısında yer alan sözcüksel ve dilbilgisel bağlaşıklı ilişkilerinden hareketle derin yapısındaki anlam ilişkilerine ulaşılır. Yani yüzey yapıda görülenden yola çıkıp, görülmeyen ya da kastedilen bulunup çıkarılır. Yüzey yapı, metnin sözdizimsel olarak üretilmiş, son halini almış şekli iken, yüzey yapının karşıt durumu olan ve metnin anlamsal ve soyut boyutunu gösteren detaylı yapı, somut yapının aksine, görünmeyen fakat algılanabilen yapısıdır. Bir metnin bağdaşık olabilmesi, metni okuyan kişilerin özelliklerine, metindeki gerçeklere, metnin yapısına ve kültürel birikimlerinden gelen önermelerle arasında bağ kurmasına bağlıdır. Metnin anlaşılması için metin-içi özelliklerin yanında bağlama ve okuyucunun bilişsel özellikleri de birer etkendir. Bu şekilde metnin yorumu durağan olmayıp okuyucunun baktı̆̆ yöne göre değişkenlik göstermektedir (Günay, 2013: 118-124; Karaağaç, 2013: 713). Metnin anlamsal yapısını irdelemek ve anlamak için belli ölçütler vardır. Bu ölçütleri: Başlık, konu, işlev, ana fikir cümlesi, anahtar sözcükler, biçem, içerik şeması, konu değişimi belirleyicileri, özet ve sonuç cümlesi olarak belirtmek mümkündür (Torusdă̆, 2013: 61).

\section{1 İşlev}

Metin, belli bir iletişim işlevi amacı olan bir dil kullanım biçimidir. Kısa öyküler de yazarlarıyla okuyucuları arasında bir iletişim aracı olan metinlerdir.

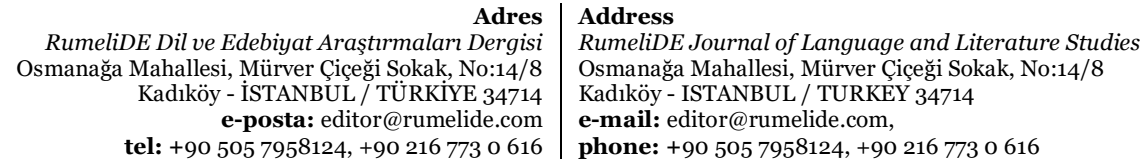


Günay’a göre, metnin işlevi, anlatıda kullanılan sunulma biçimi ve içeriğiyle ilgili bir tanımlama olup her metnin, dolayısıyla her anlatı metninin bir işlevi vardır. Hatta aynı metin içinde değişik yerlerde değişik işlevler bulunabilir. (Günay, 2013: 126). Metnin üretilme ve algılanması sürecinde, metin üreticisinin gerçekleştirmeye çalıştı̆̆ amaç yani metnin işlevi; düşündürmek, bir olayı anlatmak, bilgi vermek, eğlendirmek, heyecanlandırmak, belli tutum ve düşünce gelişimini, değişimini sağlamak, betimlemek, eleştirmek, kanıtlamak veya bir teklifte bulunmak gibi çeşitli iletişimsel amaçlar olabilir.

Bu öyküde yazar, günlük hayatta birçok insanda görülebilen kıskançlı̆̆ı dile getirirken hayatın içinden bir gerçekliğe işaret etmektedir. Gençliğin verdiği heyecanın gelip geçici olduğu hayat gerçeğinin farkında olunması gerektiği anlatılmaktadır. Hikâye hayattan bir kesit olmakla beraber bize hayatın gelip geçici olduğunu gençliğin, heyecanın bir gün yitirileceğini anlatmaya çalışıyor.

\subsection{Başlık}

Bir metnin başlı̆̆ tesadüfen seçilmeyip metnin konusu ve verilmek istenen mesajla alakalı olarak oluşturulur. Bu nedenle metinlerin başlıkları düşünerek seçilmeli ve aynı zamanda okuyucu için ilgi ve dikkat çekici nitelikte olmalıdırlar. Başlık, metnin yoğun ve çarpıcı bir yönünü ele verir. Yani metnin bütününü gözler önüne seren bir yapı barındırması gerekir (Gülensoy, 2009: 268). Kısa ve öz ifade edilen metin başlığı, metnin konusu ile alakalı kısmi bir bilgilendirme olarak tanımlanabilir.

Öykünün başlığı hem anlamlı hem de ironiktir. Başlıkta 'Bu Yollar Uzar' ile kast edilen, yolların fiziksel olarak uzayacağı değil; gençliğin gelip geçici olduğudur. Başlık hikâyenin konusu ile ilgili hem bir ipucu hem de bütün hikâyenin özeti gibidir. Öykünün sonlarında verilen Halil Usta'nın da bir zamanlar genç olduğu, gençliğinde geçtiği yolların yaşlılığında nasıl uzadığı anlatılmaktadır.

\subsection{Konu}

Metinleri oluşturan cümlelerin ve cümlelerin bir araya gelmesiyle oluşan paragrafların anlamlarının toplamından daha çok bunların arasındaki ilişkiden meydana gelen bütünsel anlamın metnin konusunu oluşturduğu aşikârdır. Metnin ana öğesini oluşturan esas unsur konudur. Bu yüzden konu, eseri oluşturan yazara duygu ve düşüncelerini aktarabilmesi için bir imkân sunar. Sonuç olarak metnin "ne anlattığı” sorusuna verilen cevap, metnin konusunu meydana getirir. Yazar hedef kitlesine göre konuyu seçip gerçekte iletmek istediği mesajları konu aracılığıyla dile getirir (Gülensoy, 2009: 267-268).

Hikâye, yeni evlenen Hayri'nin eşine olan kıskançlığının olumsuz bir durum karşısında dışa vurulmuş hâlini bize anlatır. Hikâye konusuna genel bakış açısıyla baktığımızda: hikâye, hayatı anlatmaktadır. Hikâyede zamanın geçmesiyle gençliğin yitirildiği heyecanın söndüğü konu edinmektedir.

\subsection{Anahtar sözcükler}

Anahtar sözcükler, öykünün başından sonuna kadar yinelenen, hikâyenin konusunu belirlemede ve özetlemede gerekli olan kelimelerdir. Metnin kilit sözcüklerinin belirlenmesi öncelikle o metnin dikkatli bir şekilde okunması ve anlaşılmasına bağlıdır. Anahtar kelimeler, metnin ana konusuyla ilgili bilgi veren, metnin büyük çaptaki önermelerinde ve özet metinlerin muhtevasında yer alan kelimelerdir.

Metinde en çok yinelenen 'Postacı Hayri, Hayri'nin karısı' kelimeleri metnin temelinin oluştururken ciğer, kızlar ve postahane kelimeleri de metinde sıklıkla geçen anahtar kelimelerdir.

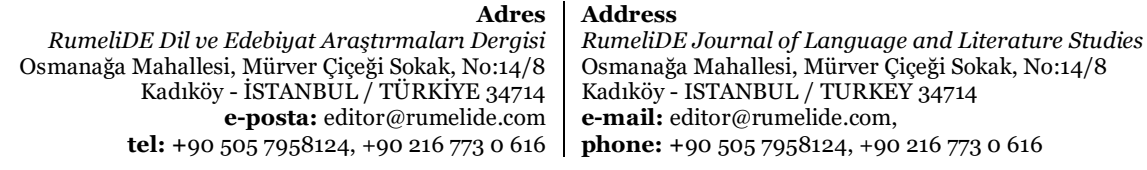




\section{5 İçerik şeması}

Metinler genel olarak üç ana unsurla açıklanır: Bunlar yapısal, işlevsel ve anlamsal yapılardır. Yazarın duygu ve düşüncelerini aktarabilmek için dili anlamsal ve mantıksal bir perspektifte sunması kendisini daha anlaşılır kılar.

Öykü bir olay öyküsü örneğidir. Olay örgüsü, her zaman ve her yerde yaşanabilecek günlük hayattan alınan bir kesintinin üzerine kurulmuştur.

Giriş Bölümü: Öykü 1. tümcede, ana karakter Hayri ’nin yaşı verilerek Hayri ile kasabın çırağı arasındaki diyalogla başlar, kasap çırağının verdiği haberin Hayri’nin içine şüphe ve ateşin düşürülmesiyle devam edip adamın aklına en olmayacak şeylerin girmesiyle son bulur. Bu bölüm, 1. ve 17. tümceler arasındadır.

Gelişme bölümü: Hayri’nin aldığı haber üzerine postanede duramaması ile başlar, evine gitmesi, evde kimseyi bulaması, kızları bahçede oynaması ile devam edip eşi hakkında düşündüklerini görememesi ve eşiyle hasret gidermesiyle son bulur. Bu bölüm 18. tümce ile 81. tümceler arsında geçer.

Sonuç bölümü: Hayri'nin evden mutlu bir şekilde ayrılmasıyla başlayıp Halil Usta'nın hayata dair tespitleriyle son bulur. Bu bölüm 82. tümce ile 106. tümceler arasında geçer.

\subsection{Ana düşünce tümcesi}

Metinlerde ana fikrin verildiği cümleler, metinde aktarılması gereken ve üzerinde durulması istenen mesajın bulunduğu kısımlardır. Metinlerde bulunan diğer önermeler bu ana düşünceyi şekillendirmek için oluşturulur. Bu nedenle büyük çaptaki önermeler yani ana düşünceyi barındıran cümleler metnin diğer tüm önermelerini kapsamalıdırlar.

Bu öykünün ana düşüncesi daha hikâyenin başlangıcı olan "Bu Yollar Uzar" başlığında bize verilmiştir. Gençliğin gelip geçici olduğu bu yılların insan üzerindeki etkisinde bahsedilmektedir.

\subsection{Sözdizimsel biçim özellikleri}

İnsan, sadece duygu ve düşüncelerini aktardığı için değil aktardıklarını belli bir biçimde gerçekleştirip dile getirdiği için yazardır (Sartre, 2015: 33). Yazarın bir metinde daima kullandığı kelimeler, dilsel kalpplar, eksiltili cümleler, bitmemiş cümleler, devrik cümle türleri, ünlem cümleleri, soru cümleleri, cümlelerin diziliş düzeni, aynı dil dışı gerçekliğe göndermede bulunan öğelerin tekrarlanması gibi küçük çaptaki yapıyı oluşturan dil unsurlarının diziliş biçimi metnin anlamı ve işlevinin meydana çıkarılması için oluşturulan biçemsel özelliklerdir.

Sözdizimsel biçem özellikleri: tek sözcüklü cümlelerle, doğrudan anlatımla, devrik yapılarla ve soru ünlem cümleleriyle yapılır. Misal, sözdizimsel bir üslup özelliği olan "soru” cümlesi kullanımı, yazarın okuyucuyu herhangi bir konu hakkında düşündürme; ünlem cümlesi kullanımı ise okuru pasif bir konumdan aktif bir konuma getirme, metni akıcı kılıp okuru metnin geriye kalan kısmı için okumaya istekli kılma gibi niyetlerinden dolayı kullanılabilir ve metnin bölümleri arasındaki bağı kurabilir.

“Kapıyı vurdun mu?”(8) Sonraki cümle için bağlantı sağlanıp akıcı bir metin özelliği yakalamaya çalışılmış

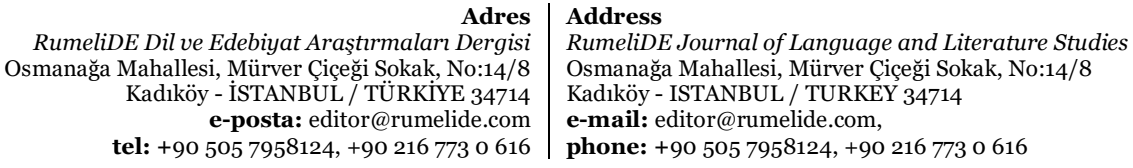


"Elbet bir şey var ki ellerim böyle titriyordu."(27) Bu cümleden gizem yaratılıp metnin sıkıcılığını ortadan kaldırmaya çalışılmıştır.

"Ulan dedi, seni alan herifin kaz kadar beyni var mı?”(68) Soru tümceleriyle de okuyucunun düşünmesi ve metne odaklanması sağlanmış.

“Canım ne yapiyorsun?...”(78)

“Çocuk musun?...”(79)

“Ne o Hayri, dedi, evden mi geliyorsun?"(88)

“Geceler yetmiyor mu?”(89)

“Git bakalım..."(93)

“Git yaaa!”(94)

“Adamın aklına en olmayacak şeyler gelir.” (17)

\subsection{Dilsel, anlamsal biçem özellikleri}

Yazınsal dil, Roman Jakobson (1960)'un belirlediği, dilin "gönderge işlevi, duygu ya da anlatım işlevi, ilişki işlevi, çağrı işlevi ve sanat işlevi ile üst-dil işlevi” olmak üzere altı işlevi olup bunlardan sanat işlevi üzerinde yoğunlaşır. Bu yüzden dil, okuyucunun dikkatini bütünüyle kendi üzerine çeker. Yazınsal dil sıradan bir araç değil amaçtır. Söz konusu amaç ise insanda güzellik duygusu uyandırmaktır. Bir metin, okuyanın dikkatini kendi üzerine çekebildiği ölçüde yazınsallık özelliği kazanır. Aksi durumda bu özellikten uzaklaşacaktır. Yazınsal dil, okuyucuyu harekete geçirebilen, ona birtakım mesajlar iletebilen, yazarın duygularını sezdirebilen bir dildir.

“Evde kimse yoktu” sözü kulağını tırmaladı.” (7)

"Yüreğimde bir sıkıntı bir ateş."(14)

“Karısını gözünden kıskanıyor.”(16)

“Bağrına basmak.”(74)

“Bu yokuşlar sana da domuzlaşır.”(100)

\subsection{Anlatıcı bakış açısı}

Bir şeyi merkeze alma, ilgiyi bir merkezde yoğunlaştırma anlamına gelen odaklayım, metinsel açıdan, metnin kim tarafından anlatıldığı, okuyucuya anlatılan olayların kimin bakış açısıyla yani kimi gözüyle ve ağzıyla iletildiğini açlklayan bir kavramdır. Metnin tam ve doğru bir çözümü için, anlatıcı ile metin arasındaki ilişkilere göre, anlatı metinlerinde üç farklı odaklayımdan bahsedilebilir: İç odaklayım, dış odaklayım ve sıfir odaklayım (Genette, (2011: 78).

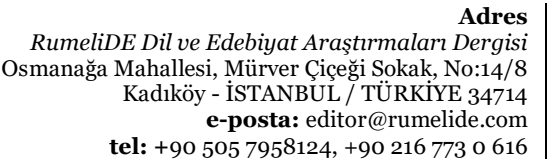

dres

RumeliDE Journal of Language and Literature Studies

Osmanağa Mahallesi, Mürver Çiçeği Sokak, No:14/8

Kadıköy - ISTANBUL / TURKEY 34714

e-mail: editor@rumelide.com,

phone: +90 $5057958124,+902167730616$ 
Sıfır odaklayımda (hâkim bakış açısı da ilahi bakış açısı) anlatıcı olan biten her şeyi görür ve bilir durumdadır. Bu yüzden, üçüncü tekil kişi anlatım yönteminin kullanıldığı sıfır odaklayım, anlatıcının her şeyi gözlemleyip bildiği ve her yerde bulunduğu sınırsız bir bakış açısı söz konusudur.

İç odaklayımda (kahraman bakış açılı birinci tekil anlatıcı) bakış açısı bir anlatı kişisinin içine yerleștirilir yani anlatıcı hikâyenin kahramanları arasında yer alır. Öyküleme ve anlatı kahramanın gördükleri ile sınırlıdır. Bu odaklayımda anlatıcı asıl karakterlerden birinin kimliğine bürünmüş gibi, o karakterin hissettiği, düşündüğü ve yaptığı şeyleri anlatan iç öyküsel kişidir.

Dış odaklayımda (gözlemci bakış açısı) anlatıcı, bir gözlemci veya tanık konumundadır. Yalnızca olayları gözlemler ve tarafsız bakış açısıyla okuyucuya anlatır.

Öyküde anlatıcı, olayların içindeki bir karakter değildir. Öykü, yer yer her şeyi bilen, her şeyi gören bir anlatıcının varlığı hissedilse de, daha çok gözlemci tanık bir anlatıcı tarafından dış odaklayım ile anlatılmıştır.

\subsection{0 Özet}

Beaugrande ve Dressler'e (1981) göre, tipik bir metin özeti, o metnin büyük ölçekli yapısı üzerine kurulmalıdır. Metnin özetinin sunulması metindilbilimsel bir ifadeyle, 'silme, genelleme ve kurma' gibi geniş kapsamlı yapı kurallarını işleterek bir metnin yapısının çıkarılmasını gerektirir.

Hikâye, postacı ve yeni evli olan 26 yaşındaki Hayri’nin evine kuzu ciğeri gönderip de evde kimsenin olmadığını öğrenmesiyle başlar. Eşini kıskanan Hayri bu durumdan işkillenir ve içindeki ateş ve sıkıntıyla eşine bakmaya gider. Ancak evine gittiğinde eşinin kız kardeşiyle ve arkadaşlarıyla arka bahçede oynadığını görür ve içindeki sıkıntı da sona erer. Evden dönen Hayri’nin Halil Usta ile karşılaşmasında ustanın ona gençliğin geçiciliği ve yaşlılıktaki hayatın zorluğu hakkında hayata dair gerçekleri anlatması ile hikâyemiz son bulur.

\subsection{Sonuç tümcesi}

Metinlerin son cümleleri, metnin başlangıç cümleleriyle ile bir köprü durumundadır. Bu cümleler metnin içeriğini özetleyici niteliktedir ve okuyucu kitlesini belirli olaylara yönlendirir. Okuyucuda yaratılmak istenen tavrın ve gelişimin belirgin veya kapalı olarak ifade edildiği mühim kısımlardır. Bu sebeple metinlerde son cümlelerinin kurulması metinlere başlık bulmak kadar güçtür. Metinlerde, metnin büyük çaptaki örgüsüyle kesişen bir sonuç cümlesi kesinlikle olmalıdır.

Hikâyenin son tümcesi: Çoktan yokuşu inmiş, belki postaneye de varmıştır.(106) Bu tümce metnin ana düşüncesiyle alakalı olup insanın gençliğinde yolları hızlı geçtiğini hayatı çabuk yaşadığını anlatmaktadır.

\section{Sonuç}

$\mathrm{Bu}$ çalışmayla özet bir metindilbilim analizi yapılmak istenmiş ve metindilbilimin ana faktörleri olan kavramlar, kaideler doğrultusunda Memduh Şevket Esendal'ın "Bu Yollar Uzar" adlı hikâyesi üzerinde durulmuştur. Bu eserin seçilmiş olması metindilbilimsel bir araştırmaya uygun olmasından ve esasında kısa bir öykü olmasından kaynaklanır. Metnin analizinde kullandı̆̆ımız metotlar söylem çözümlemesi ve metindilbilimi yönünden etkili bir yeri olan küçük çaplı yapı, (sözcüksel bağlaşıklık, eşdizimsel

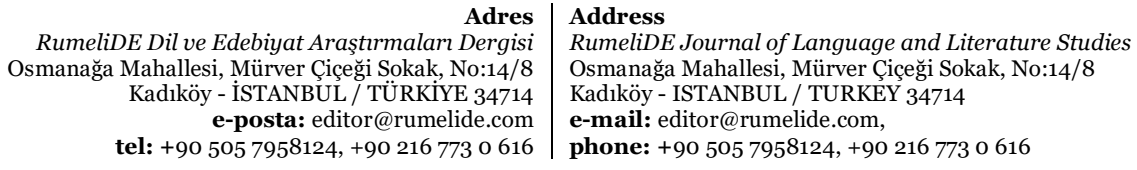


örüntüleme, yineleme, dilbilgisel bağlaşıklı, gönderim, zaman uyumu ve görünüş eksilti bağıntı öğeleri, işlevsel cümle yapısı ve örtük anlatım) büyük çaplı/bağdaşıklık (başlık, konu, işlev, içerik şeması, anahtar sözcükler, konu cümlesi/ana fikir cümlesi, dilsel, anlamsal biçem özellikleri, sözdizimsel biçem özellikleri, anlatıcı bakış açısı, özet ve sonuç tümcesi) biçimlerinin bulunmasından oluşmaktadır. Burada geçen her bir başlık adı altında metin analiz edilmiştir. Önce kısaca metotlarla ilgili bilgi verilmiş, sonrasında da analizlerin daha çok anlaşılması için hikâyeden emsaller verilerek hikâyenin anlaşırlığı sağlanmıştır. Bununla birlikte metnin dilbilimsel ve dil bilgisel örtük yapıları, eksik yapıları ele alınarak metnin görünen ve görünmeyen bölümleri ortaya konulmaya çalışılmıştır. Sözün kısası bu analizdeki asıl amaç, metnin esas konusu ve bu esas konuyu oluşturan alt konuların saptanması ayrıca metnin anlaşlan, görünen bölümüyle birlikte metinde saklı olan faktörlerin yani metnin derin yapısının ortaya çıarılmasıdır.

Sonuç olarak esere yönelik yapılan çözümleme ile küçük çaplı yapı/bağlaşıklık ve büyük çaplı/bağdaşıklı görünümlerinin güçlü bir şekilde oluşturulduğu tespit edilmiştir. Yüzey yapıdaki somut bağlaşıklık verilerinden hareketle soyut olan derin yapıya inildiğinde günlük hayat içerisinde insanı anlamaya çalışan bir durum tespit edilmiştir. Anlık yanılgıların insanın iç dünyasında nasıl şekillendiği gözler önüne serilmiştir. Bu eserle "Memduh Şevket Esendal” tam anlamıyla hayatın bir kesitini ele alıp okuyucuya sunmaya çalışmıştır.

\section{Kaynakça}

Akbayır, Sıddık (2004). “Metin Bilgisi: Okuma, Anlama, Yorumlama, Çözümleme”, Samsun: Deniz Kültür.

Beaugrand, Robert Alain de ve DRESSLER, Wolfgang (1981). Introductionto Text Linguistics. Londonand New York: LongmanGroup Limited.

Erden, Aysu ( 2002). “Kısa Öykü ve Dilbilimsel Eleştiri”, İstanbul: Gendaş Kültür.

Gansel, Christina - Jürgens, Frank (2002). "TextlinguistikundTextgrammatik. EineEinführung", Wiesbaden:WestdeutscherVerlag. Sosyal Bilimler Enstitüsü Dergisi Sayı : 21 Yll : 2006/2 (191204 s.) 204.

Gülensoy, Tuncer (2009). "Kompozisyonla İlgili Genel Bilgiler.” Türk Dili ve Kompozisyon. Bursa: Ekin Basım Yayın Dağıtım. Hazırlayanlar: Zeynep Korkmaz, Ahmet B. Ercilasun, Tuncer Gülensoy, İsmail Parlatır, Hamza Zülfikar, Necat Birinci. Genişletilmiş 3. Baskı.

Günay, Doğan (2013). Metin Bilgisi. İstanbul: Papatya Yayıncılık Eğitim A.Ş.

Günay, Doğan ( 2018). “Söylem Çözümlemesi”, İstanbul: Papatya Yayıncllı Eğitim.

Dilidüzgün, Şükran (2008). Türkçe Öğretiminde Metindilbilimsel Bağlamda Uygulamalı Bir Yaklaşım. İstanbul Üniversitesi Sosyal Bilimler Enstitüsü Türkçe Eğitimi Anabilim Dalı Doktora Tezi, İstanbul.

Genette, Gerard (2011). Anlatının Söylemi, Çev.: Ferit Burak Aydar, İstanbul: Boğaziçi Üniversitesi, S. 78.

Halliday, M. A. K., Hasan, R. (1976). Cohesion in English. London: Longman

Hengirmen, Mehmet ( 1999) "Dildilgisi ve Dilbilim Terimleri Sözlüğü”, Ankara: Engin.

Jakobson, Roman (1960). "LinguisticsandPoetics", İçinde T. Sebeok, (Yay.)., Style in Language, Cambridge, MA: M.I.T. Press, ss. 350-377

Karaağaç, Günay (2013). Türkçenin Dil Bilgisi. Ankara: Akçă̆.

Sayın, Şara ( 1999), “Deneme: Metinlerle Söyleşi”, İstanbul: Multilungual.

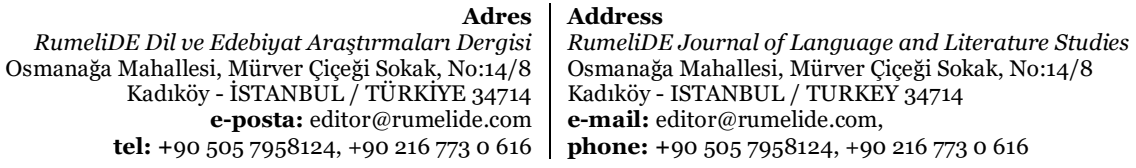


Subaşı- Uzun, Leyla ( 1995). “Orhun Yazıtlarının Metindilbilimsel Yapısı”, Türk Dilleri Araştırmaları Dizisi, Ankara.

Şenöz Ayata, Canan (2005). Metindilbilim ve Türkçe. İstanbul: MultilingualAraştırmaları Dizisi.

Türkçe Sözlük (2005). Ankara: Türk Dil Kurumu.

Torusdă̆, Gülssen (2013). Metindilbilime Genel Bir Bakış ve Metindilbilimsel Bir Çözümleme Örneği Olarak Ömer Seyfettin'in "İlk Cinayeti”. Yüzüncü Yıl Üniversitesi Sosyal Bilimler Enstitüsü Dergisi, 24, 42-84.

Aydın, İlker ve TORUSDAĞ, Gülşen (2013). Lamartine'in Göl 'Le Lac' Şiirine Metindilbilimsel Bir Yaklaşım. Turkish Studies, 8(10), 105-114.

Aydın, İlker ve TORUSDAĞ, Gülşen (2014). Türkçe Öğretimi Çerçevesinde Yazınsal Bir Metin Çözümleme Örneği Olarak Refik Halit Karay’ın Garip Bir Hediye'si. Uluslararası Türkçe Edebiyat Kültür Eğitim Dergisi, Sayı: 3/4, s. 109-134,

Uzun, L. S. (1995). Orhon Yazıtlarının Metindilbilimsel Yapısı. Ankara: Simurg Kitapçılık ve Yayıncılık Limited Şirketi.

Vardar, Berke (1988). Açılamalı Dilbilim Terimleri Sözlüğü. İstanbul: ABC Kitabevi.

Vater, Heinz (1994). "Einführung in dieTextlinguistik”, München: Fink.

Yıldırım, Ali ve ŞİMŞEK, Hasan (2003). Sosyal Bilimlerde Nitel Araştırma Yöntemleri. Ankara: Seçkin

RumeliDE Dil ve Edebiyat Araştırmaları Dergisi Osmanağa Mahallesi, Mürver Çiçeği Sokak, No:14/8 Kadıköy - ISTANBUL / TÜRKIYE 34714 e-posta: editor@rumelide.com tel: +90 505 7958124, +90 2167730616
Address

RumeliDE Journal of Language and Literature Studies Osmanağa Mahallesi, Mürver Çiçeği Sokak, No:14/8

Kadıköy - ISTANBUL / TURKEY 34714

e-mail: editor@rumelide.com,

phone: +90 $5057958124,+902167730616$ 